ADVISORY BOARD

Coretta Scott King (chair)

Christine King Farris

Lerone Bennett, Jr.

Ira Berlin

Samuel Dubois Cook

John Hope Franklin

David J. Garrow

Robert L. Green

Vincent Harding

Louis R. Harlan

Robert A. Hill

Darlene Clark Hine

Bernard Lafayette

John D. Maguire

Otis Moss

Joseph Roberts, Jr.

Preston N. Williams

Harris Wofford

Andrew J. Young 
The publishers gratefully acknowledge the many individuals and foundations that have contributed to the publication of the Papers of Martin Luther King, Jr., and the General Endowment Fund of the Associates of the University of California Press for its contribution toward the publication of this volume.

Our special thanks to Maya Angelou,

Sukey Garcetti, Maxine Griggs, Mary Jane Hewitt, Franklin Murphy, Joan Palevsky, and Marilyn Solomon for their leadership during the campaign.

\section{Challenge Grant}

Times Mirror Foundation

Leadership Grants

The Ahmanson Foundation

AT\&T Foundation

Partners

ARCO Foundation

William H. Cosby and Camille O. Cosby

The George Gund Foundation

The Walter and Elise Haas Fund LEF Foundation

Sally Lilienthal

J. Michael Mahoney

The Andrew W. Mellon Foundation

National Historical Publications and Records Commission

Peter Norton Family Foundation

Joan Palevsky

The Ralph M. Parsons Foundation 


\author{
Benefactors \\ Anonymous \\ BankAmerica Foundation \\ Fleishhacker Foundation \\ David Geffen Foundation \\ Linda Johnson Rice-Johnson Publishing Company \\ Koret Foundation \\ Levi Strauss Foundation \\ Lilly Endowment Inc. \\ McDonnell Douglas Foundation \\ Foundations of the Milken Families \\ National Endowment for the Humanities \\ Pacific Telesis Group \\ Jocelyn, Drew, and Keith Reid \\ Charles H. Revson Foundation, Inc. \\ Ernst D. and Eleanor Slate van Löben Sels Foundation
}

\author{
Patrons \\ Earl and June Cheit \\ Berry Gordy_Jobete Music Publishing Co., Inc. \\ Frances and Kenneth Reid \\ Sponsors \\ Jacqueline and Clarence Avant \\ Edward R. Bradley, Jr. \\ Francine and Kevin Castner \\ Esther Gordy Edwards-Motown Museum \\ Susan and August Frugé \\ Deborah and Joseph Goldyne \\ Hugh Hefner \\ Beatrice and Richard Heggie \\ Quincy Jones-Quincy Jones Productions \\ Max Palevsky \\ The Roth Family Foundation \\ Sony Corporation of America
}


